\title{
The response of cucumber plants (Cucumis sativus L.) to the application of PCB-contaminated sewage sludge and urban sediment
}

\author{
Anna Wyrwicka ${ }^{\text {Corresp., }} 1$, Magdalena Urbaniak ${ }^{2}$, Mirosław Przybylski $^{3}$ \\ 1 Department of Plant Physiology and Biochemistry, Faculty of Biology and Environmental Protection, University of Lodz, Lodz, Poland \\ 2 European Regional Centre for Ecohydrology, Polish Academy of Sciences, Lodz, Poland \\ 3 Department of Ecology and Vertebrate Zoology, Faculty of Biology and Environmental Protection, University of Lodz, Lodz, Poland \\ Corresponding Author: Anna Wyrwicka \\ Email address: anna.wyrwicka@biol.uni.lodz.pl
}

Background. The increasing production of sewage sludge (SS) engenders the problem of its responsible utilization and disposal. Likewise, urban sediments (SED) are deposited at the bottom of urban reservoirs and sedimentation ponds, and these require periodical dredging and utilization. However, while the SS and SED deposits often contain nutrients such as nitrogen and phosphorus; however, they also contain a variety of hazardous compounds including heavy metals, Persistent Organic Pollutants (POPs) and microbial pollutants. Fortunately, some species of Cucurbitaceae can accumulate high levels of POPs, such as polychlorinated dibenzo-p-dioxins (PCDD), polychlorinated dibenzofurans (PCDF) and polychlorinated biphenyls (PCB), in their tissues.

Methods. SS was collected from the Lodz Municipal Wastewater Treatment Plant and SED from the Sokołówka Sequential Biofiltration System. The SS and SED samples were added to soil in flower pots at three concentrations ( $1.8 \mathrm{~g}, 5.4 \mathrm{~g}$ and $10.8 \mathrm{~g}$ per flower pot), and one pot was left as an unamended control (C). Soil PCB concentrations were determined before cucumber planting, and after five weeks of growth. Also, total soluble protein, total chlorophyll content, chlorophyll a/b ratio and degree of lipid peroxidation (TBARS) were examined in the leaves of the cucumber plants (Cucumis sativus L.) Cv. Cezar after five weeks. Antioxidative response was assessed by ascorbate peroxidase (APx) and catalase (CAT) assay.

Results. The initial PCB concentration in soil after application of SS or SED was dependent on the applied dose. After five weeks, PCB concentration fell significantly for all samples and confirmed that the dose of SS/SED had a strong effect. Soil remediation was found to be more effective after SS application. Total soluble protein content in the cucumber leaf tissues was dependent on both the type and the dose of the applied amendments, and increased with greater SS doses in the soil. The total chlorophyll content remained unchanged, and the chlorophyll a/b ratio was slightly elevated only after the application of the highest SS and SED dose. The use of SS and SED did not significantly affect TBARS content. APx activity fell after SS or SED application; however, CAT activity tended to increase, but only in the leaves of plants grown in SS-amended soil.

Discussion. The cultivation of cucumber plants reduces PCB concentration in soil amended with SS or SED; however, this effect is more evident in the case of SS. SS application also induced more intensive changes in the activity of enzymes engaged in antioxidative response and oxidative stress markers in plant tissues than SED. The levels of PCB in the SS may have triggered a more severe imbalance between pro- and antioxidative reactions in plants. Cucumber plants appear to be resistant to the 
presence of toxic substances in SS and SED, and the addition of SS and SED not only acts as a fertilizer, but also protects against accelerated aging. 
1 The response of cucumber plants (Cucumis sativus L.) to the application of PCB-

2 contaminated sewage sludge and urban sediment

3

4 Anna Wyrwicka1, Magdalena Urbaniak2, Mirosław Przybylski3

5

61 Department of Plant Physiology and Biochemistry, Faculty of Biology and Environmental

7 Protection, University of Lodz, Banacha 12/16, 90-237 Lodz, Poland

8 phone: +48 4263544 16; fax: +48 4263544 23; e-mail: anna.wyrwicka@,biol.uni.lodz.pl; web:

9 www.biol.uni.lodz.pl

112 European Regional Centre for Ecohydrology of the Polish Academy of Sciences, Tylna 3, 90-

$12364 \mathrm{Lodz}$, Poland

13 phone: +48 4268170 06; fax: +48 4268130 69; e-mail: m.urbaniak@,unesco.lodz.pl; web:

14 www.erce.unesco.lodz.pl

15

16

3 Department of Ecology and Vertebrate Zoology, Faculty of Biology and Environmental

17 Protection, University of Lodz, Banacha 12/16, 90-237 Lodz, Poland

18 phone/fax: +48 4263558 17; e-mail: miroslaw.przybylski@biol.uni.lodz.pl;

19 web: www.biol.uni.lodz.p1

Corresponding Author

26 Anna Wyrwicka

27 anna.wyrwicka@biol.uni.lodz.pl

28

29

30 
Background. The increasing production of sewage sludge (SS) engenders the problem of its responsible utilization and disposal. Likewise, urban sediments (SED) are deposited at the bottom of urban reservoirs and sedimentation ponds, and these require periodical dredging and utilization. However, while the SS and SED deposits often contain nutrients such as nitrogen and phosphorus; however, they also contain a variety of hazardous compounds including heavy metals, Persistent Organic Pollutants (POPs) and microbial pollutants. Fortunately, some species of Cucurbitaceae can accumulate high levels of POPs, such as polychlorinated dibenzo- $p$-dioxins (PCDD), polychlorinated dibenzofurans (PCDF) and polychlorinated biphenyls (PCB), in their tissues.

Methods. SS was collected from the Lodz Municipal Wastewater Treatment Plant and SED from the Sokołówka Sequential Biofiltration System. The SS and SED samples were added to soil in flower pots at three concentrations (1.8 g, $5.4 \mathrm{~g}$ and $10.8 \mathrm{~g}$ per flower pot), and one pot was left as an unamended control (C). Soil PCB concentrations were determined before cucumber planting, and after five weeks of growth. Also, total soluble protein, total chlorophyll content, chlorophyll $\mathrm{a} / \mathrm{b}$ ratio and degree of lipid peroxidation (TBARS) were examined in the leaves of the cucumber plants (Cucumis sativus L.) cv. Cezar after five weeks. Antioxidative response was assessed by ascorbate peroxidase (APx) and catalase (CAT) assay.

Results. The initial PCB concentration in soil after application of SS or SED was dependent on the applied dose. After five weeks, PCB concentration fell significantly for all samples and confirmed that the dose of SS/SED had a strong effect. Soil remediation was found to be more effective after SS application. Total soluble protein content in the cucumber leaf tissues was dependent on both the type and the dose of the applied amendments, and increased with greater $\mathrm{SS}$ doses in the soil. The total chlorophyll content remained unchanged, and the chlorophyll a/b ratio was slightly elevated only after the application of the highest SS and SED dose. The use of SS and SED did not significantly affect TBARS content. APx activity fell after SS or SED application; however, CAT activity tended to increase, but only in the leaves of plants grown in SS-amended soil. 
63 Discussion. The cultivation of cucumber plants reduces PCB concentration in soil amended with

64 SS or SED; however, this effect is more evident in the case of SS. SS application also induced more intensive changes in the activity of enzymes engaged in antioxidative response and oxidative stress markers in plant tissues than SED. The levels of PCB in the SS may have triggered a more severe imbalance between pro- and antioxidative reactions in plants. Cucumber plants appear to be resistant to the presence of toxic substances in SS and SED, and the addition of SS and SED not only acts as a fertilizer, but also protects against accelerated aging.

\section{Introduction}

The 21 st century set a new challenge for mankind, that of reconciling economic development with the preservation and protection of global natural resources. This goal can be achieved through adopting a sustainable development strategy, which is based on fast economic growth and improvements in quality of life, coupled with the improvement of the natural environment and the protection of its resources (EC, 2017). Maintaining a balance between the above is possible only through the rational use of natural resources and limiting the environmental burden associated with waste coming from human activity. In response to the development of urban centers and the changes in consumption habits of the population, municipal waste management has become a priority environmental issue in many countries. Waste administration also represents a significant cost to society. As the global population grows, the amount of waste, including domestic wastewater, increases with it. The development of universal sewage systems requires a greater number of wastewater treatment plants, resulting in growing amounts of the product of wastewater treatment, this being sewage sludge (SS).

Urban sediments (SED) are formed at the bottom of treatment reservoirs and sedimentation ponds located in cities. One example of such structures is the Sokołówka Sequential Biofiltration System (SSBS), whose sediments were used in the present study (Urbaniak et al., 2012). The SSBS was constructed in the upper section of the Sokołówka River with the aim of removing sediments, suspended solids, particulate pollutants, petroleum hydrocarbons, heavy metals and nutrients from stormwater runoff through a system of sedimentation and filtration mechanisms. In order to increase the efficiency of the system, it comprises three different zones: a hydrodynamically-intensified sedimentation zone, an intensive biogeochemical process zone and an intensive biofiltration zone. 
94 Both SS and SED are rich organic fertilizers. They contain a number of nutrients that are 95 essential for agricultural use, such as nitrogen and phosphorus (Herzel et al., 2016; Mamedov et 96 al, 2016; Tontti, Poutiainen \& Heinonen-Tanski, 2017). Organic fertilization results in an 97 increase in the organic carbon and nitrogen stock in soils and is more effective than mineral 98 fertilization (Yazdani et al., 2017; Wyrwicka \& Urbaniak 2018). The presence of increased 99 amounts of soil organic matter also improves soil structure, water holding capacity and soil 100 nutrient availability, increases microbial biomass and broadens microbial community structure 101 and biodiversity (Tejada et al., 2014; Lloreta et al., 2016). However, in addition to substances 102 that bestow a beneficial effect on plants and enrich the soil, SS and SED also contain heavy 103 metals, toxic organic and inorganic pollutants, including a number of persistent organic 104 pollutants (POPs) characterized by high persistence, potential for bioaccumulation, 105 biomagnifications and toxicity, e.g. polychlorinated biphenyls (PCBs), polychlorinated dibenzo106 -dioxin (PCDD), polychlorinated dibenzofurans (PCDFs), polycyclic aromatic hydrocarbons

107 (PAH); in addition, inorganic compounds, silicates and aluminates can also be found, as well as 108 pathogenic and other microbial pollutants (Oleszczuk, 2006; Urbaniak et al., 2017b; Goberna et 109 al., 2018).

110 In accordance with sustainable development strategy principles, SS and SED should be rationally 111 and responsibly managed so as not to pose a threat to human health and life. Landfilling, 112 incineration, composting and agricultural use are all used for waste control in Europe. However 113 the Landfill Directive 99/31/EC (CEU, 1999) and the statutes of Poland and other member 114 countries place very strict limits on organic matter or total organic carbon content in sludge.

115 These limits have effectively prevented the use of landfilling as a means of disposal. Hence, the

116 first choice for sludge disposal indicated by European Environmental Policy (Decision 117 2001/118/EC; Directive 2008/98/EC; CEC, 2001) is total sludge reuse, with agricultural use 118 being the obvious mode. However, due to the elevated concentrations of heavy metals in SS, 119 which are regulated at national (Journal of Laws of 2015, item 257) and EU levels (Sewage 120 Sludge Directive, 86/ 278/EEC; CEC, 1986), this approach cannot be used by agriculture for 121 food production.

122 A method that addresses the problem of increasing amounts of SS and SED is phytoremediation. 123 It is a technique based on the ability of selected plant species to remove, contain or render 124 harmless environmental contaminants (Cunningham \& Berti 1993; Cunningham, Berti \& Huang, 
125 1995; Macek, Macková \& Káš, 2000). This "green technology" is a cost-effective, non-invasive, 126 alternative or complementary technology for site restoration and partial decontamination 127 (Wiesmeier et al., 2015; Glenn, Jordan \& Waugh, 2017). Phytoremediation is a promising 128 method of coping with the growing production of SS and urban reservoir sediments, particularly 129 in cities, where they could be used by direct application as soil additives on city gardens and 130 lawns. The plants used in phytoremediation should not only have a high ability to neutralize 131 pollutants, but should also be resistant to the effects of these pollutants on plant organisms.

132 Although many examples have been given of plant species capable of remediation of heavy 133 metals (Ivanov, Bystrova \& Seregin, 2003; Reddy et al., 2005; Lyubenova et al., 2009), the 134 processes of phytoremediation of organic substances are not so well understood and further 135 information is still needed on this subject. The main problem associated with the potential for 136 phytoremediation of organic compounds is related to their hydrophobicity, and hence the 137 inability of plants to take up these compounds from the soil ( $\log \mathrm{K}_{\mathrm{ow}}$ between 5.0 to 8.3). 138 Substances with a $\log \mathrm{K}_{\mathrm{ow}}$ higher than 3.5 are not available for most plants, because they are 139 strongly bound to soil particles and do not go into the soil solution from where they may be taken 140 up by the roots (Briggs, Bromilow \& Evans, 1982; Hatzinger \& Alexander, 1995). Many 141 excellent publications indicate that the plants of the Cucurbitaceae, such as cucumbers, pumpkins 142 and squashes are exceptions to this rule. These plants have a high potential to take in relatively 143 large amounts of organic compounds and to accumulate them in their tissues. In addition, it was

144 found that the collected compounds come largely from the substrate in which the plants were 145 grown rather than from the air (Hülster, Müller \& Marschner, 1994; Engwall \& Hjelm, 2000;

146 Mattina, Iannucci-Berger \& Dykas, 2000; White, 2002; Mattina et al., 2004; Zhang et al., 2004;

147 Inui et al., 2008; Low et al., 2010; White, 2010; Matsuo et al., 2011).

148 SS and SED offer great potential as fertilizers which also improve the physicochemical 149 properties of soil due to their high organic matter content. On the other hand, the presence of 150 harmful substances in the sediments may adversely affect plant physiology and influence total 151 soluble protein content, total chlorophyll content as well as chlorophyll a/b ratio, among others. 152 However, most research on the effects of SS or SED on plants focuses mainly on growth 153 parameters such as biomass yield (Urbaniak et al., 2017a). Only a few works investigate the 154 influence of these sediments on physiological and biochemical changes occurring in treated 155 plants (Lakhdar et al., 2010). 
156 Environmental stress factors have been demonstrated to result in delayed secondary oxidative 157 stress in plants (Demidchik, 2015). This state is characterized by the imbalance between the 158 formation of Reactive Oxygen Species (ROS) and their removal by the cellular antioxidant 159 systems. ROS such as superoxide anions $\left(\mathrm{O}_{2}^{-\bullet}\right)$, hydroxyl radicals $\left({ }^{\circ} \mathrm{OH}\right)$ and peroxyl radicals 160 (ROO'), singlet oxygen $\left({ }^{1} \mathrm{O}_{2}\right)$ and hydrogen peroxide $\left(\mathrm{H}_{2} \mathrm{O}_{2}\right)$ are highly reactive and can cause 161 oxidative damage to proteins, lipids, nucleic acids and other biologically important molecules;

162 this damage results in dysfunction and irreversible degradation, and thus reduced plant growth 163 and development (Gill \& Tuteja, 2010). Although ROS are naturally formed under physiological 164 conditions in plant cells as by-products of photosynthesis and respiration, the homeostasis 165 between their production and elimination is not maintained under oxidative stress. One of the 166 consequences of the occurrence of oxidative stress in plant tissues is the increase in the concentration of compounds reacting with thiobarbituric acid (ThioBarbituric Acid Reactive

168 Substances; TBARS). In plant cells, many elements of the antioxidant system interact with each

169 other to counteract ROS accumulation. One of the components of the enzymatic antioxidant 170 system is ascorbate peroxidase (APx), which reduces $\mathrm{H}_{2} \mathrm{O}_{2}$ to water with simultaneous oxidation 171 of the substrate, ascorbic acid. Another antioxidant enzyme is catalase (CAT), which catalyzes 172 the $\mathrm{H}_{2} \mathrm{O}_{2}$ dismutation reaction.

173 The aim of the study was to determine the effect of SS and SED contamination of soil on 174 cucumber cultivation, with regard to their potential as soil remediation agents. The study 175 examines total soluble protein and total chlorophyll content, and chlorophyll a/b ratio in the 176 plants to identify the physiological status. To determine if the given conditions affect the redox 177 equilibrium, the extent of the oxidative reaction was assessed as TBARS content, and efficiency 178 of the antioxidative system was assessed as the activities of APx and CAT.

Materials and methods

181 Soil preparation

182 Two sets of samples were collected from two locations in Central Poland: SS from Lodz 183 Municipal Wastewater Treatment Plant (LM WWTP) and SED from the Sokołówka Sequential 184 Biofiltration System (SSBS). The SED samples used in the experiment were collected from the 185 first zone of the SSBS, intended for accelerated sedimentation of suspended matter and 186 associated pollutants. The SS and SED samples were dried at $70{ }^{\circ} \mathrm{C}$ for 72 hours then 
187 homogenized into small particles using a mortar and used as fertilizer for the soil samples for

188 cucumber planting. The vegetable potting soil, intended for cucumber growth, used in the 189 experiment was collected from Hollas Sp. z o.o. Pasłęk. The main soil parameters used in this 190 experiment was presented in Table 1.

191 In addition to controls, in which no sludge or sediment was added (C), three treatments were 192 used: $1.8 \mathrm{~g}, 5.4 \mathrm{~g}$ and $10.8 \mathrm{~g}$ of dried matter per flower pot. The first corresponds to a dose of 3 193 tonnes $\mathrm{ha}^{-1}$, the annual dosage permitted by the Ministry of the Environment of Regulations 194 (Journal of Laws of 2015, item 257); the second is the permitted dose of 9 tonnes ha-1 per three 195 years applied on one occasion; and the third, 18 tonnes $\mathrm{ha}^{-1}$ is above the permitted level. 196 Treatments are designated by the dose per pot.

PCB concentrations

199 PCB concentrations were determined in the control and SS and SED amended soils before cucumber planting, i.e. the first day of the experiment, and after five weeks of cucumber growth, 201 i.e. the last day of the experiment. The collected soil samples were stored in glass tubes in the 202 dark at $4{ }^{\circ} \mathrm{C}$ for further extraction using a PCB RaPID Assay Sample Extraction Kit (Modern 203 Water) and PCB analysis using Enzyme Linked Immunosorbent Assay (ELISA) - PCB RaPID 204 Assay (Modern Water). PCB extraction and level determination were performed according to the 205 manufacturer's instructions (

206 Assay PCB.pdf).

207 The PCB RaPID Assay kit applies the principles of ELISA to the determination of PCB and 208 related compounds (EPA SW-846 Method \#4020). The test sample is added to a disposable test 209 tube with an enzyme conjugate, followed by paramagnetic particles bound to antibodies specific 210 to PCB. Both the PCB in the sample and the enzyme-labeled PCB (the enzyme conjugate) 211 compete for the antibody binding sites on the magnetic particles. After a short incubation period, 212 the PCB and the labeled PCB analog will bind to the particles at proportions reflecting their 213 concentrations in the suspension. A magnetic field is then applied to hold the particles in the tube 214 and the unbound reagents are decanted. After decanting, the particles are washed with Washing 215 Solution. The presence of PCB is detected by adding the enzyme substrate (hydrogen peroxide) 216 and the chromogen (3,3',5,5'-tetramethylbenzidine). The enzyme labeled PCB analog bound to

217 the PCB antibody catalyses the conversion of the substrate/chromogen mixture to a colored 
218 product. After an incubation period, the reaction is stopped and stabilized by the addition of acid.

219 Since the labeled PCB (conjugate) was in competition with the unlabeled PCB (sample) for the

220 antibody sites, the color developed is inversely proportional to the concentration of PCB in the

221 sample. The absorbance was measured at $450 \mathrm{~nm}$ using a SDI Differential Spectrophotometer.

222 A fuller description of sample preparation was also given previously by Wyrwicka, Steffani \&

223 Urbaniak, 2014.

224

225 Plant material

226 Cucumber seeds (Cucumis sativus L.) cv. Cezar were germinated in Petri dishes for seven days

227 and the seedlings were planted in the control or amended soil. The samples were grown in a 228 growth chamber at of $23 \pm 0.5^{\circ} \mathrm{C}$ under a $16 \mathrm{~h} \mathrm{light} / 8 \mathrm{~h}$ dark cycle, $250 \mu \mathrm{mol} \mathrm{m} \mathrm{m}^{-2} \mathrm{~s}^{-1}$ photon flux 229 density, during the light period, and $60 \%$ relative humidity. Five-week old plants with five fully-

230 expanded leaves were used for subsequent analysis. All biochemical analyses were carried out on

231 the physiologically second, third and fourth leaves (from the bottom) of the control and treated

232 plants. The leaves were harvested in the middle of the 16-hour light period.

233

234 Preparation of enzyme extracts from leaf tissues

235 The leaves of the cucumber plants were ground $(1: 10, \mathrm{w} / \mathrm{v})$ in an ice-cold mortar using $50 \mathrm{mM}$ 236 sodium phosphate buffer ( $\mathrm{pH} 7.0$ ) containing $0.5 \mathrm{M} \mathrm{NaCl}, 1 \mathrm{mM}$ EDTA, and $1 \mathrm{mM}$ sodium 237 ascorbate. The slurry was filtered through two layers of Miracloth. The filtrates of homogenized 238 cucumber leaves were then centrifuged ( $15000 \mathrm{~g} \mathrm{x} 15 \mathrm{~min}$ ). After centrifugation, the supernatant 239 was collected and APx and CAT activities as well as protein content and degree of lipid 240 peroxidation were measured.

242 Enzyme assay

243 APx activity [EC 1.11.1.11] was assayed following the oxidation of ascorbate to 244 dehydroascorbate at $265 \mathrm{~nm}\left(\varepsilon=13.7 \mathrm{mM}^{-1} \mathrm{~cm}^{-1}\right)$ according to Nakano \& Asada (1981) with 245 some modifications, using a Unicam UV 300 UV-Visible spectrometer (Unicam Limited, 246 Cambridge United Kingdom). The assay mixture contained $50 \mathrm{mM}$ sodium phosphate buffer $\mathrm{pH}$ $247=7.0,0.25 \mathrm{mM}$ sodium ascorbate, $25 \mu \mathrm{M} \mathrm{H}_{2} \mathrm{O}_{2}$ and the enzyme extract (5-10 $\mu \mathrm{g}$ protein). The 248 addition of $\mathrm{H}_{2} \mathrm{O}_{2}$ started the reaction. The obtained values were compared with those of another 
249 reaction mixture without the enzyme extract to correct for non-enzymatic oxidation of ascorbate.

250 The enzyme activity was expressed in $\mu \mathrm{mol}$ ascorbate $\mathrm{mg}^{-1}$ protein.

251 CAT activity [EC 1.11.1.6] was measured spectrophotometrically according to Dhindsa, Plumb-

252 Dhindsa \& Thorpe, 1981. A reaction mixture composed of $50 \mathrm{mM}$ sodium phosphate buffer ( $\mathrm{pH}$ $253=7.0), 15 \mathrm{mM} \mathrm{H}_{2} \mathrm{O}_{2}$ and the enzyme extract (5-10 $\mu \mathrm{g}$ protein) was used. The decomposition of $254 \mathrm{H}_{2} \mathrm{O}_{2}\left(\varepsilon=45.2 \mathrm{mM}^{-1} \mathrm{~cm}^{-1}\right)$ was measured at $240 \mathrm{~nm}$ using Unicam UV 300 UV-Visible 255 spectrometer (Unicam Limited, Cambridge United Kingdom). CAT activity was expressed in $256 \mathrm{mmol} \mathrm{H}_{2} \mathrm{O}_{2} \mathrm{mg}^{-1}$ protein.

257

258 Protein content

259 The protein content was determined according to Bradford (1976) with standard curves prepared 260 using bovine serum albumin. Samples were assayed using a spectrophotometer (Helios Gamma, 261 Thermo Spectronic, Cambridge, UK). The protein content was given as $\mathrm{mg} \mathrm{g}^{-1}$ fresh mass of the 262 original plant tissue.

263

264 Degree of lipid peroxidation (TBARS)

265 Concentration of lipid peroxides was estimated spectrofluorometrically (F-2500 Fluorescence 266 Spectrophotometer, Hitachi, Limited, Tokyo Japan) according to Yagi (1982), by measuring the 267 content of 2-thiobarbituric acid reactive substances (TBARS). The concentration of lipid 268 peroxides was calculated in terms of 1,1,3,3-tetraethoxypropane, which was used as a standard 269 and expressed in $\mathrm{nmol} \mathrm{g}^{-1}$ fresh mass.

270

271 Determination of chlorophyll content

272 Whole leaves were homogenized $(1: 5 \mathrm{w} / \mathrm{v})$ in an ice-cold mortar using $50 \mathrm{mM}$ sodium phosphate 273 buffer, $\mathrm{pH}$ 7.0, containing $0.5 \mathrm{M} \mathrm{NaCl}, 1 \mathrm{mM}$ EDTA and $1 \mathrm{mM}$ sodium ascorbate. Crude 274 homogenate obtained after filtration was assayed for chlorophyll content according to Porra, 275 Thompson \& Kriedmann (1989). The absorbance of clear supernatant obtained after 276 centrifugation (5000 $\mathrm{g} \times 5 \mathrm{~min}$.) of $80 \%$ acetone extract was measured at 663 and $645 \mathrm{~nm}$ using 277 a Helios Gamma spectrophotometer (Thermo Spectronic, Cambridge, UK). The concentration of 278 chlorophyll was expressed as $\mathrm{mg} \mathrm{g}^{-1}$ fresh mass. 
280 Statistical analysis

281 Linear regression analysis was used to describe the relationships between PCB concentration in

282 soil and amendments dose separately for SS and SED. To analyze whether both regression lines

283 differed significantly, differences in slopes (b coefficient) was tested using a t-test and if the null

284 hypothesis were not rejected, the differences in intercepts (a coefficient) were also tested (t-test)

285 (Zar, 2010). The effect of cucumber plant cultivation on the PCB content in soil amended with

286 SS and SED was analyzed by two-way ANOVA (repeated measures) with type of soil 287 amendments and their dose as factors.

288 Six to eight individuals were collected from the cultivated plants and used for the experiment,

289 hence the replicate number of plant biochemical parameters varies from six to eight $(\mathrm{n}=6-8)$.

290 Two-way analysis of variance (ANOVA II) was used to test the effects of both SS and SED and

291 their content in the soil on plant biochemical parameters (i.e. protein concentration, APx, CAT,

292 TBARS and chlorophyll concentration as well as chlorophyll $\mathrm{a} / \mathrm{b}$ ratio). Before this, compliance

293 with ANOVAs assumptions i.e. the normal distribution and the homoscedicity of variance had

294 previously been checked by the Shapiro-Wilk test and Levene's test, respectively. If the analysis

295 of variance showed a significant effect of any of the factors, a multiple-comparison least

296 significant difference (LSD Fisher) post hoc test was used (Zar, 2010). All analyses were

297 performed using STATISTICA 13 software (Dell Inc., 2016).

298

299 Results

300 In general, the PCB concentration (average \pm SD) in soil amended with SS $(0.931 \pm 0.284)$ and

301 in the soil enriched using $\operatorname{SED}(0.898 \pm 0.245)$ did not differ significantly $(\mathrm{t}=0.6226 ; \mathrm{df}=8 ; \mathrm{p}=$

302 0.5436). In both types of soil amendments, the PCB concentration was related to SS/SED dose;

303 the equations describing these linear relationships were as follows: $\mathrm{PCB}=0.7043+0.0505 \times$

304 amendments dose $\left(\mathrm{r}^{2}=0.6139 ; \mathrm{p}=0.0214\right)$ for SS; PCB $=0.6206+0.0507 \times$ amendments dose

$305\left(\mathrm{r}^{2}=0.8361 ; \mathrm{p}=0.0015\right)$ for SED. Covariance analysis revealed a lack of significant differences

306 in $\mathrm{b}$ (slope) coefficients $(\mathrm{t}=0.01483$; $\mathrm{df}=12 ; \mathrm{p}=0.9883)$ and a (intercept) coefficients $(\mathrm{t}=$

307 1.1113; $\mathrm{df}=13 ; \mathrm{p}=0.2865)$. After five weeks of cultivation, the mean reduction of PCB was

$30838.47 \%$ for the SS-treated soil and $27.62 \%$ for the SED-treated soil (Fig. 1.). However, two-way

309 analysis of variance (repeated measures ANOVA II) showed that the reduction of PCB content in

310 soil was significant $(\mathrm{F}=22.1443 ; \mathrm{df}=1,8 ; \mathrm{p}=0.0015)$ and did not depend on the type of 
311 amendments used $(\mathrm{F}=0.2091 ; \mathrm{df}=1,8 ; \mathrm{p}=0.6596)$ but confirmed the strong effect of the

$312 \mathrm{SS} / \mathrm{SED}$ dose $(\mathrm{F}=10.1274 ; \mathrm{df}=3,8 ; \mathrm{p}=0.0042)$ (Fig. 2a; Fig. 2b). Moreover, there were no

313 types of significant interactions between analyzed factors (Table 2). Post hoc comparisons (the

314 LSD test) revealed significant reductions of PCB concentration for all doses of SS (Fig. 2a) but

315 no significant effect of remediation was observed in the case of SED (Fig. 2b).

316 Changes in soluble protein content in cucumber leaf tissues were dependent on both the type and

317 the dose of the applied amendment (Fig. 3). Two-way analysis of variance (ANOVA II) showed

318 the effect of the type of amendments used on protein content $(\mathrm{F}=15.736 ; \mathrm{df}=1,46 ; \mathrm{p}=$

$3190.000253)$ as well as the effect of SS/SED dose in the soil on soluble protein content $(\mathrm{F}=9.651$;

$320 \mathrm{df}=3,46 ; \mathrm{p}=0.000047$ ). In the case of SS, the multiple comparisons (LSD Fisher) test revealed

321 significant effect of its dose on the leaf protein content. An increasing trend was observed

322 regarding the soluble protein content in leaf tissues together with used dose: 116\% of control

323 value for $1.8,129 \%$ for 5.4 and $136 \%$ for 10.8 . However, the use of SED did not significantly

324 alter the content of soluble protein in cucumber tissues: the only significant difference was found

325 between the 1.8 and 10.8 SED doses. Moreover, a significant interaction (type of amendment $\times$

$326 \mathrm{SS} / \mathrm{SED}$ dose) was also noted $(\mathrm{F}=4.340 ; \mathrm{df}=3,46 ; \mathrm{p}=0.00894)$. The multiple comparisons

327 (LSD Fisher) test showed that this interaction was significant: no differences in leaf protein

328 content were observed between control, low (1.8) and medium (5.4) of SED doses.

329 Two-way analysis of variance (ANOVA II) did not show the influence of the type of

330 amendments used on the total chlorophyll content value $(\mathrm{F}=1.342 ; \mathrm{df}=1,46 ; \mathrm{p}=0.2527)$, nor

331 did it indicate that SS/SED dose in the soil had any effect on the value of total chlorophyll

332 content $(\mathrm{F}=0.531 ; \mathrm{df}=3,46 ; \mathrm{p}=0.664)$ (Table 3$)$.

333 In contrast to total chlorophyll content, the chlorophyll $\mathrm{a} / \mathrm{b}$ ratio depended significantly on the

334 type of amendments used $(\mathrm{F}=12.05 ; \mathrm{df}=1,40 ; \mathrm{p}=0.001257)$ and the dose of amendments

335 added to the soil $(\mathrm{F}=7.77 ; \mathrm{df}=3,40 ; \mathrm{p}=0.000334)$. The multiple comparisons (LSD Fisher)

336 test showed that the highest dose of both SS and SED used increases the chlorophyll a/b ratio up

337 to $105.7 \%$ and to $103.1 \%$ of the control value (Table 3). An analysis of both total chlorophyll

338 content and chlorophyll $\mathrm{a} / \mathrm{b}$ ratio revealed no statistically significant interactions with the type of

339 amendments used and its dose in the soil.

340 Neither SS nor SED enrichment caused any significant change in the TBARS content, which 341 represents an indicator of oxidative lipid damage (Fig. 4). Two-way analysis of variance 
342 (ANOVA II) did not show the influence of the type of amendments used on TBARS value $(\mathrm{F}=$ $3430.4392 ; \mathrm{df}=1,40 ; \mathrm{p}=0.511)$. The analysis also did not confirm that SS/SED dose in the soil 344 influenced TBARS level $(\mathrm{F}=2.370 ; \mathrm{df}=3,40 ; \mathrm{p}=0.085)$. The multiple comparisons (LSD 345 Fisher) test revealed SS only demonstrated a significant effect at the 5.4 dose, where TBARS 346 value achieved $130 \%$ of control. There were no statistically significant interactions between the 347 analyzed factors.

348 Two-way analysis of variance (ANOVA II) did not show the influence of the type of 349 amendments used on APx activity, a key antioxidant enzyme in plants $(\mathrm{F}=0.2915 ; \mathrm{df}=1,40 ; \mathrm{p}$ $350=0.5923$ ). Contrary, dose-dependent changes in the activity of APx were observed after both SS 351 and SED application $(\mathrm{F}=13.1692 ; \mathrm{df}=3,40 ; \mathrm{p}=0.000004)$ (Fig. 5). The multiple comparisons 352 (LSD Fisher) test revealed that SS dose had a significant effect on enzyme activity: APx activity 353 was strongly reduced to $48 \%, 49 \%$ and $45 \%$ of control value in the low (1.8), medium (5.4) and 354 high (10.8) doses, respectively. Similar changes were observed after applying SED, where a 355 decrease in APx activity was observed for the medium (5.4) and high (10.8) doses, these being $35666 \%$ and $55 \%$ of control values, respectively. There were no statistically significant interactions 357 between the analyzed factors.

358 The activity of CAT, the other enzyme involved in antioxidant defense, depended on the type of 359 soil amendment $(\mathrm{F}=119.198 ; \mathrm{df}=1,40 ; \mathrm{p}=0.000000)$ and $\mathrm{SS} / \mathrm{SED}$ dose $(\mathrm{F}=7.834 ; \mathrm{df}=3,40$;

$360 \mathrm{p}=0.000314)$. Two-way analysis of variance also showed significant interaction between factors

$361(\mathrm{~F}=6.003 ; \mathrm{df}=4,40 ; \mathrm{p}=0.00178)$. However, the multiple comparisons (LSD Fisher) test 362 revealed that SS dose had a significant effect on CAT activity, but no difference was observed 363 between control and the lowest dose (1.8) and between medium (5.4) and high (10.8) doses; in 364 addition, SED dose did not significantly affect enzyme activity (Fig. 6).

365

366 Discussion

367 The most important task of phytoremediation is to reduce the levels of toxic substances in the 368 water, sediment, soil or air in a particular environment. Many plants can be used for 369 phytoremediation; however, their physiological condition will be affected to varying degrees by 370 the toxicity of the environment, and this in turn will influence their removal efficiency. With this 371 in mind, the members of the Cucurbitaceae are particularly good candidates for the 
372 phytoremediation of PCBs from the substrate (Mattina, Iannucci-Berger \& Dykas, 2000; White 373 et al., 2002).

374 Despite being banned in the 1970s because of their negative impact on the environment and 375 human health, PCBs are highly persistent and require removal from the environment. Of the 376 various PCB reclamation methods available, such as incineration and landfilling, a cost-effective 377 and environmentally-friendly approach is phytoextraction (Low et al., 2010). The ability of 378 plants to remediate PCBs from the soil is influenced by the properties of the mixture of PCB 379 congeners contained in the substrate and the possibility of their uptake by plants. It has been 380 shown that the degree of chlorination, $\log \mathrm{K}_{\mathrm{ow}}$ and molecular size are the most important factors 381 determining the possibility of absorption and transport for PCBs and other hydrophobic POPs 382 (Greenwood, Rutter \& Zeeb, 2011).

383 Our present findings indicate that irrespective of whether SS or SED was added to the soil, the 384 PCB concentration in the amended soil at the beginning of experiment was similar and 385 dependent on the dose of applied amendments. In addition, after five weeks of cucumber 386 cultivation, lower PCB levels were observed in all soil samples; however, this effect was greater in the SS amended soil, where as much as a $41 \%$ decrease in PCB concentration was found compared to the initial value. These values suggest a stronger reduction in PCB content than noted in previous studies. For example, Qin, Brookes \& Xu (2014) report that 60-day cultivation of cucumber plants reduced the PCB content by $19.5 \%$ compared to unplanted soil. The authors suggest that one of the important factors determining the effectiveness of phytoremediation may

392 be the presence and composition of microbial communities responsible for PCB degradation.

393 The rhizosphere is a space in which root exudates are released to the soil, and these may 394 selectively foster the growth of PCB-degrading bacteria. The effectiveness of PCB remediation 395 may, therefore, not only be conditioned by the species, or variety of the plant involved in 396 phytoremediation, but also by the composition and origin of the sediments containing PCBs. As 397 the SS and the SED used in the present study most likely possess different microbial 398 compositions, it is not surprising that they were associated with different degrees of PCB 399 reduction.

400 Differences between the type of applied amendment (SS or SED), influencing the degree of 401 decrease of PCB concentration in the studied soil (revealed by the LSD test), may indicate that 402 the ability to remediate PCBs from amended soil by cucumber plants may depend on the origin 
403 of the amendments used, and hence on the composition of the soil. It can not be ruled out that the

404 ability to remediate PCBs may depend on the presence of other toxic substances in the substrate 405 that can cause adverse effects on plants. A study of the remediation potential of zucchini 406 (Cucurbita pepo L.) in soil samples treated with PCDD/PCDF-contaminated SS or SED found 407 the PCDD/PCDF content to be up to 2.7 times greater in the soil treated with SS than in that 408 treated with SED (Urbaniak et al., 2016). However, the presence of these compounds in the SS409 treated soil did not reduce its level of phytoremediation; in fact, the level was even greater than 410 in the SED soil.

411 While the cucumber plants treated with SS demonstrated gradual increases in total soluble 412 protein content with increasing doses of the applied sludge, no significant changes were found in 413 plants growing on soil with SED. An elevated total protein content may indicate that the 414 presence of SS has a beneficial effect on the physiological condition of the plant. From the 415 physiological point of view, it is known that the soluble protein content in plants decreases 416 during the course of senescence (Camp et al., 1982; Romanova et al., 2016). This is related to the 417 initiation of the N-remobilization process, during which proteinase activity increases, leading to 418 the degradation of proteins to peptides or amino acids, which are then transported to the growing 419 organs in the phloem sap (Girondé et al., 2015). Hence, the increase in soluble protein content 420 observed in cucumber tissues growing in SS amended soil may indicate a delay of the processes 421 of senescence. Protein content in plant tissues may also increase due to abiotic stresses such as 422 heat or drought (Grigorova et al., 2011). In the case of cucumber plants studied in this work, the 423 thesis about increasing the protein content resulting from stress seems unlikely, if only due to the 424 lack of a significant increase in TBARS content in plants treated with SS and SED, which is a 425 measure of oxidative damage of lipids as well as due to the lack of lowering total chlorophyll 426 content in leaf tissues.

427 This increase in total soluble protein content in the leaf tissues of cucumber cultivated on soil 428 treated with SS, combined with the apparent lack of influence of SS and SED contamination on 429 total chlorophyll content, i.e. no decrease was observed, may be another indicator that the 430 examined plants are in good physiological condition and the applied amendments may have a 431 strong fertilizing effects. The results of both the total protein and chlorophyll content obtained in 432 this study show that senescence progresses faster in control plants than in plants fertilized with 433 SS as well as the use of SED also do not intensify the processes associated with senescence. 
434 The physiological condition of the plant can also be evaluated my measuring chlorophyll $\mathrm{a} / \mathrm{b}$ 435 ratio. It was found that chlorophyll $\mathrm{a} / \mathrm{b}$ ratio increased slightly in the plants treated with the 436 highest dose (10.8) of SS, as well as with SED, in comparison with control. As mentioned 437 earlier, total chlorophyll content together with chlorophyll $\mathrm{a} / \mathrm{b}$ ratio may be indicators of the 438 initiation of senescence process in plants and gradual changes in the biochemical processes 439 associated with them. A decrease in leaf chlorophyll content is one of the first symptoms of plant 440 senescence, which is characterized by the breakdown of thylakoid membranes and the 441 degradation of thylakoid-bound proteins. The presence of the aging process is further confirmed 442 by a depressed chlorophyll a/b ratio. For example, in a study of Arabidopsis thaliana plants, the 443 chlorophyll a/b ratio was found to decrease linearly with natural leaf senescence, as did total 444 chlorophyll content; differential degradation of chlorophyll a and chlorophyll b was also 445 observed during senescence, resulting in changes in chlorophyll a/b ratio (Nath et al., 2013). In 446 the case of the cucumber plants studied in the present work, it can be assumed that the addition 447 of SS and SED not only acts as a fertilizer, but also serves a protective function against the 448 accelerated aging process. Our findings also highlight another important point: cucumber plants 449 may well be resistant to toxic effects of substances contained in SS.

450 TBARS content is a commonly-used indicator of oxidative stress following environmental stress 451 (Srivastava, Sinha \& Sharma, 2017). In the present study, both after applying SS and SED, there 452 were no changes in TBARS content in cucumber leaves that could indicate oxidative damage of 453 lipids. The only exception is the increase in the value of this parameter (up to $130 \%$ of control) 454 after application of SS at the medium (5.4) dose. Page et al. (2014) report lower application rates 455 of compost-like-output result in nitrate leaching, and note that this could be a limiting factor in 456 the use of sludge as a nutrient source. It is also possible that the advantages of sludge application 457 associated with nutrient content are outweighed by the presence of toxic compounds when 458 applied at low doses: Higher doses of sludge are richer in nutrients, and this compensates for the 459 effects of the presence of harmful substances. Similarly, SS was found to have a protective effect 460 on alfalfa plants (Medicago sativa L. cv. Aragon) subjected to additional drought stress: Its 461 addition led to a significant reduction malondialdehyde in nodules resulting from lipid 462 peroxidation, while this number was strongly increased in the nodules of untreated plants 463 subjected to drought (Antolin, Muro \& Sanchez-Diaz, 2010). A similar beneficial result was obtained by Tartoura \& Youssef (2011) regarding the use of compost for the cultivation of 
465 squash (Cucurbita pepo L. cv. Eskandarany) exposed to low temperature conditions, with both 466 oxidative damage of lipids and ROS generation being markedly reduced following compost 467 application.

468 Our present findings also indicate differences in the plant response to the use of SS and SED. 469 Although the soil PCB concentrations at the beginning of the experiment did not differ 470 significantly and depended only on the dose of the amendments used, the response of plants 471 growing on SS and SED-amended soil varies. It is very likely that such a situation would be 472 attributed to the composition of soil after addition of SS or SED. It can not be ruled out that SS is 473 more toxic than SED and the two can vary to a great degree regarding their remaining content.

474 Earlier studies carried out on willow plants indicate that the composition of SS and its impact on 475 plants is dependent on the size of the sewage treatment plant (Wyrwicka \& Urbaniak, 2018). For 476 example, unlike the sludge produced by large, industrialized urban centers, like that used in the 477 present work, sludge from plants operating in small agglomerations does not typically contain 478 large amounts of substances harmful to plants, such as heavy metals.

479 APx is an enzyme characteristic of plant tissues. It is characterized by high substrate specificity 480 and is sensitive to substrate concentration; during its absence in the surrounding solution, the 481 enzyme is inhibited. This enzyme may also be inactivated by $\mathrm{H}_{2} \mathrm{O}_{2}$. It is also an important 482 element of the ascorbate-glutathione cycle, which maintains the reduction-oxidation balance in 483 plant cells (Asada, 1992). Of the parameters measured in the present study, APx was found to 484 display the greatest changes in activity, with decreases being observed both after applying SS 485 and SED. In the case of SS, the lowest applied dose (1.8) already inhibited the enzyme activity 486 (up to $48 \%$ of control), whereas after the SED application, the APx activity decreased only when 487 the medium (5.4) and high (10.8) doses were used. This may suggest that both SS and SED may 488 contain compounds that inhibit APx activity and it cannot be ruled out that $\mathrm{H}_{2} \mathrm{O}_{2}$ would 489 accumulate in the cells under these conditions. On the other hand, while APx activity was 490 significantly reduced, an increase in CAT activity was observed in the plant tissues exposed to 491 the same dose (5.4 and 10.8) of SS present in soil. It is possible that the increase in CAT activity 492 has a compensatory effect on inhibited APx activity in investigated cucumber tissues. 493 Furthermore, CAT activity, whose primary function it is to remove $\mathrm{H}_{2} \mathrm{O}_{2}$ from cells, in tobacco 494 cell suspension culture exposed to $\mathrm{PCDD} / \mathrm{Fs}$ showed an upward trend with increasing PCDD/Fs 495 concentration (Zhang et al., 2012). 
496 The decrease in APx activity observed herein may also be attributed to a lack of ascorbate, its

497 substrate, which may have been consumed elsewhere by non-enzymatic antioxidative reactions.

498 Our observations regarding APx activity and the total protein content can be compared with the

499 those of Aki, Güneysu \& Acar (2009), who studied the reaction of four plant species, viz. tomato,

500 pepper, bean and broad bean, on industrial wastewater. Total protein content increased in all of

501 the tested plants during the experiment, while peroxidase activity decreased following exposure.

502 The elevated CAT activity observed in the present study after the application of the medium

503 (5.4) and high (10.8) doses of SS could be result of an efficiently functioning antioxidative

504 system in the cucumber tissues: It can be assumed that increased CAT activity protected the

505 tissues of the investigated cucumber plants from oxidative damage, which can be proved only by

506 a small increase in the TBARS content in one of the applied concentration variants (5.4). As it

507 appears from the results obtained, after using a higher dose (10.8) of SS, elevated CAT activity

508 was probably effective in protecting plant tissues from the effects of oxidative stress, because in

509 any of the variants elevated TBARS content was found. It cannot be ruled out that changes in

510 CAT activity after SS are related to the size of the dose of amendment. A previous study on

511 wheat (Triticum durum) exposed to different doses of SS found CAT activity in the leaves to be

512 unaffected when the sludge was applied in small doses, but significantly elevated at higher doses

513 (Lakhdar et al., 2010).

514 The increase in total protein content and chlorophyll $\mathrm{a} / \mathrm{b}$ ratio observed in the present study, as

515 well as the changes in CAT activity and lack of the increase of TBARS content (found only in 516 one case), indicate that the plants fertilized with SS fared better than the unfertilized controls,

517 and this suggests that cucumber plants are well suited to phytoremediation of PCBs. Our results

518 suggest that cucumber plants are able to trigger a defensive response based on the action of the

519 antioxidant system, such as CAT activity, that allows them to survive adverse environmental 520 conditions and resist the effects of toxicity.

521

\section{Conclusions}

523 Our findings indicate that the cucumber is perfectly suitable for reducing PCB content in soil

524 treated with SS or SED in a relatively short time, while appearing relatively resistant to the toxic

525 substances present in the applied amendment. The data concerning total protein content, total 526 chlorophyll content and chlorophyll a/b ratio indicates that plants treated with SS or SED fared 
527 better than untreated controls, with the greatest response displayed by those treated with SS. The

528 cucumber plants treated with SS or the SED possessed an effective, functioning antioxidative 529 system which protected the plants against the occurrence of oxidative damage. Therefore, 530 cucumber plants are ideal candidates for the phytoremediation of this type of soil pollution. 531 However, further studies are needed to integrate the knowledge regarding the mechanism of PCB 532 action and activation of plant protective systems, as well as the interdependence between the 533 plants and microbes responsible for PCB degradation, in order to improve the efficiency of the 534 phytoremediation process and adapt it to practical applications.

535

536

537

538

539

540

541

542

543

544

545

546

547

548

549

550

551

552

553

\section{References}

Aki C, Güneysu E, Acar O. 2009. Effect of industrial wastewater on total protein and the peroxidase activity in plants. African Journal of Biotechnology 8: 5445-5448.

Antolín MC, Muro I, Sánchez-Díaz M. Sewage sludge application can induce changes in antioxidant status of nodulated alfalfa plants. Ecotox Environ Safe. 2010; 73: 436-442.

Asada K. 1992. Ascorbate peroxidase - a hydrogen peroxide-scavenging enzyme in plants. Physiologia Plantarum 85: 235-241.

Bradford MM., 1976. A rapid and sensitive method for the quantification of microgram quantities of protein utilizing the principle of protein-dye binding. Anal Biochem. 72, 248-254.

Briggs GG, Bromilow RH, Evans AA. 1982. Relationships between lipophilicity and root uptake and translocation of non-ionised chemicals by barley. Pesticide Science 13 (5): 495504.

554 January 2001 Amending Decision 2000/532/EC as Regards the List of Wastes (2001/118/EC)

Camp, P.J., Huber, S.C., Burke, J.J., Moreland, D.E., 1982. Biochemical changes that occur during senescence of wheat leaves. Plant Physiology 70, 1641-1646.

CEC (Council of the European Communities), 1986. Council Directive of 12 June 1986 on the protection of the environment, and in particular of the soil, when sewage sludge is used in agriculture (86/278/EEC). Official Journal of the European Communities No. L 181/6-12.

CEC (Council of the European Communities), 2001. Commission Decision of 16

555 (Official Journal of the European Communities No. L 47/1-31).

556

CEU (Council of the European Union), 1999. Council Directive of 26 April 1999, on

557 the Landfill of Waste (99/31/EC) (Official Journal of the European Union No. L 182/1-19). 
Dell Inc. (2016). Dell Statistica (data analysis software system), version 13.

559 software.dell.com.

560

Demidchik V. 2015. Mechanisms of oxidative stress in plants: From classical chemistry

561 to cell biology. Environmental and Experimental Botany 109; 212-228

562 http://dx.doi.org/10.1016/j.envexpbot.2014.06.021

563 Dhindsa, R.S., Plumb-Dhindsa, P., Thorpe, T.A., 1981. Leaf senescence: correlated

564 with increased levels of membrane permeability and lipid peroxidation, and decreased levels of

565 superoxide dismutase and catalase. J. Exp. Bot. 32, 93-101.

566 EC (European Commission), 2017. EU Sustainable Development Strategy. Available

567 from: http://ec.europa.eu/environment/sustainable-development/strategy/index_en. htm

Engwall M, Hjelm K. 2000. Uptake of dioxin-like compounds from sewage sludge into

569

570

571

572

573

574

575

576

577

578

579

580

581

582

583

584

585

586 various plant species-assessment of levels using a sensitive bioassay. Chemosphere. 40 (9-11): 1189-1195. PMID: 10739061

Gill SS, Tuteja N. 2010. Reactive oxygen species and antioxidant machinery in abiotic stress tolerance in crop plants Plant Physiology and Biochemistry 48; 909-930

Girondé, A., Poret, M., Etienne, P., Trouverie, J., Bouchereau, A., Le Cahérec, F., Leport, L., Orsel, M., Niogret, M-F., Deleu, C., Avice, J-C., 2015. A profiling approach of the natural variability of foliar $\mathrm{N}$ remobilization at the rosette stage gives clues to understand the limiting processes involved in the low $\mathrm{N}$ use efficiency of winter oilseed rape. Journal of Experimental Botany 66, 2461-2473.

Glenn, E.P., Jordan, F., Waugh, W.J., 2017. Phytoremediation of a nitrogencontaminated desert soil by native shrubs and microbial processes. Land Degradation and Development 28, 361-369.

Greenwood SJ, Rutter A, Zeeb BA. 2011. The absorption and translocation of polychlorinated biphenyl congeners by Cucurbita pepo ssp. pepo. Environ Sci Technol. 45 (15), 6511-6516. doi: 10.1021/es200598u PMID: 21696136

Grigorova B, Vaseva II, Demirevska K, Feller U. 2011. Expression of selected heat shock proteins after individually applied and combined drought and heat stress. Acta Physiol. Plant. 33, 2041-2049. DOI 10.1007/s11738-011-0733-9 
Hatzinger PB, Alexander M. 1995. Effect of aging of chemicals in soil on their

588 biodegradability and extractability. Environmental Science and Technology 29 (2): 537-545.

589 doi: 10.1021/es00002a033 PMID: 22201403

590

Herzel, H., Krüger, O., Hermann, L., Adama Ch., 2016. Sewage sludge ash - A

591 promising secondary phosphorus source for fertilizer production. Science of the Total

592 Environment 542, 1136-1143.

593

Hülster A, Müller JF, Marschner H. 1994. Soil-plant transfer of polychlorinated dibenzo-p-dioxins and dibenzofurans to vegetables of the cucumber family (Cucurbitaceae). Environmental Science Technology; 28 (6): 1110-1115. doi: 10.1021/es00055a021 PMID: 22176237

Inui H, Wakai T, Gion K, Kim YS, Eun H. 2008. Differential uptake for dioxin-like 598 compounds by zucchini subspecies. Chemosphere. 73 (10): 1602-1607. doi: 10.1016/j.chemosphere.2008.08.013 PMID: 18835616

Ivanov VB, Bystrova EI, Seregin IV. Comparative impacts of heavy metals on root growth as related to their specificity and selectivity. Russian Journal of Plant Physiology 2003; 602 50 (3): 398-406.

Lakhdar A, ben Achiba W, Montemurro F, Jedidi N, Abdelly Ch. 2009. Effect of 604 municipal solid waste compost and farmyard manure application on heavy-metal uptake in wheat. Commun Soil Sci Plan. 40: 3524-3538. doi: 10.1080/00103620903326040 Delgado Juárezd, M., Goberna, M. 2016. Sewage sludge addition modifies soil microbial communities and plant performance depending on the sludge stabilization process. Applied Soil Ecology 101, 37-46.

Low JE, Whitfield Åslund ML, Rutter A, Zeeb BA. 2010. Effect of plant age on PCB

611 accumulation by Cucurbita pepo ssp. pepo. Journal of Environmental Quality 39 (1): 245-50. 612 doi: 10.2134/jeq2009.0169 PMID: 20048312

613 Lyubenova L, Nehnevajova E, Herzig R, Schröder P. 2009. Response of antioxidant 614 enzymes in Nicotiana tabacum clones during phytoextraction of heavy metals. Environmental 615 Science and Pollution Research 16 (5): 573-581.

616 Macek, T., Macková , M., Káš, J., 2000. Exploitation of plants for the removal of 617 organics in environmental remediation. Biotechnology Advances 18, 23-34. 
619 Levy, G. J., 2016. Amending soil with sludge, manure, humic acid, orthophosphate and phytic 620 acid: effects on infiltration, runoff and sediment loss. Land Degradation and Development 27, $621 \quad 1629-1639$.

622 Marta Goberna, Pedro Simón, María Teresa Hernández, Carlos García. 2018.

623 Prokaryotic communities and potential pathogens in sewage sludge: Response to wastewaster 624 origin, loading rate and treatment technology. Science of the Total Environment 615, 360-368. 625 https://doi.org/10.1016/j.scitotenv.2017.09.240

626 Matsuo S, Yamazaki K, Gion K, Eun H, Inui H. 2011. Structure-selective accumulation 627 of polychlorinated biphenyls in Cucurbita pepo. Journal of Pesticide Science 36: 363-369.

628 Mattina MI, Eitzer BD, Iannucci-Berger W, Lee WY, White JC. 2004. Plant uptake and 629 translocation of highly weathered, soil-bound technical chlordane residues: Data from field and 630 rhizotron studies. Environmental Toxicology and Chemistry 23 (11): 2756-2762. PMID: 63115559292

632 Mattina MJI, Iannucci-Berger W, Dykas L. 2000. Chlordane uptake and its 633 translocation in food crops. Journal of Agricultural and Food Chemistry 48 (5): 1909-1915.

634 Nakano Y, Asada K. Hydrogen peroxide is scavenged by ascorbate-specific peroxidase 635 in spinach chloroplasts. Plant Cell Physiol. 1981; 22: 867-880.

636 Nath, K., Phee, B-K., Suyeong, J., Lee, S.Y., Tateno, Y., Allakhverdiev, S.I., Lee, Ch637 H., Nam, H.G., 2013. Age-dependent changes in the functions and compositions of 638 photosynthetic complexes in the thylakoid membranes of Arabidopsis thaliana. Photosynthesis 639 Research 2013, 117, 547-556.

640 Oleszczuk, P. 2006. Persistence of polycyclic aromatic hydrocarbons (PAHs) in sewage 641 sludge amended soils. Chemosphere 65, 1616-1626.

642 Page K, Harbottle MJ, Cleall PJ, Hutchings TR. 2014. Heavy metal leaching and 643 environmental risk from the use of compost-like output as an energy crop growth substrate 644 Science of the Total Environment 487; 260-271

645 Porra, R.J., Thompson,W.A., Kriedmann, P.E., 1989. Determinate of accurate 646 extinction coefficients and simultaneous equations for assaying chlorophylls $\mathrm{a}$ and $\mathrm{b}$ extracted 647 with four different solvents: verification of the concentration of chlorophyll standards by atomic 648 absorption spectroscopy. Biochim. Biophys. Acta 975, 384-39. 
Qin H, Brookes PC, Xu J. 2014. Cucurbita spp. and Cucumis sativus enhance the 650 dissipation of polychlorinated biphenyl congeners by stimulating soil microbial community 651 development. Environmental Pollution 184; 306-312

652 Reddy AM, Kumar SG, Jyothsnakumari G, Thimmanaik S, Sudhakar Ch. Lead induced 653 changes in antioxidant metabolism of horsegram (Macrotyloma uniflorum (Lam.) Verdc.) and 654 bengalgram (Cicer arietinum L.). Chemosphere. 2005; 60(1): 97-104. PMID: 15910908 Romanova, A.K., Semenova, G.A., Ignat'ev, A.R., Novichkova, N.S., Fomina, I.R., 656 2016. Biochemistry and cell ultrastructure changes during senescence of Beta vulgaris L. leaf. Protoplasma 253, 719-727.

S.D. Cunningham, W.R. Berti, J.W. Huang. 1995. Phytoremediation of contaminated soils Trends in Biotechnology, 13, 393-397.

S.D. Cunningham, W.R. Berti. 1993. Remediation of contaminated soils with green plants: an overview. In Vitro Cellular \& Developmental Biology - Plant, 29P, 207-212

Srivastava S, Sinha P, Sharma J K. 2017. Status of pfotosynthetic pigments, lipid 663 peroxidation and anti-oxidative enzymes in Vigna mungo in presence of arsenic. Journal of Plant 664 Nutrition 40: 298-306. doi: 10.1080/01904167.2016.1240189

Tartoura KAH, Youssef SA. 2011. Stimulation of ROS-scavenging systems in squash 666 (Cucurbita pepo L.) plants by compost supplementation under normal and low temperature 667 conditions. Scientia Horticulturae 130; 862-868

Tejada, M., Gómez, I., Fernández-Boy, E., Díaz, M.-J. 2014. Effects of sewage sludge and Acacia dealbata composts on soil biochemical and chemical properties. Communications in Soil Science and Plant Analysis 45, 570-580.

Tontti, T., Poutiainen, H., Heinonen-Tanski, H. 2017. Efficiently treated sewage sludge supplemented with nitrogen and potassium in a good fertilizer for cereals Land Degradation and Development 28, 742-751.

Urbaniak M, Wyrwicka A, Zieliński M, Mankiewicz-Boczek J. 2016. Potential for phytoremediation of PCDD/PCDF-contaminated sludge and sediments using Cucurbitaceae plants: A pilot study. Bulletin of Environmental Contamination and Toxicology 97: 401-406. DOI 10.1007/s00128-016-1868-6

Urbaniak, M., Skowron, A., Zieliński, M., Zalewski, M., 2012. Hydrological and environment al conditions as key drivers for spatial and seasonal changes in PCDD/PCDF 
680 concentrations, transport and deposition along urban cascade reservoirs. Chemosphere 88, 13586811367.

682

Urbaniak, M., Wyrwicka, A., Tołoczko, W., Serwecińska, L., Zieliński, M., 2017b. The 683 effect of sewage sludge application on soil properties and willow (Salix sp.) cultivation. Science 684 of the Total Environment 586, 66-75.

Urbaniak, M., Zieliński, M., Wyrwicka, A., 2017a. The influence of the Cucurbitaceae 686 on mitigating the phytotoxicity and PCDD/PCDF content of soil amended with sewage sludge. 687 International Journal of Phytoremediation 19, 207-213.

White JC. 2002. Differential bioavailability of field-weathered p,p'-DDE to plants of 689 the Cucurbita and Cucumis genera. Chemosphere. 49 (2): 143-152. PMID: 12375861

White JC. 2010. Inheritance of p,p'-DDE phytoextraction ability in hybridized 691 Cucurbita pepo cultivars. Environmental Science and Technology 44 (13): 5165-5169. doi: 692 10.1021/es100706t PMID: 20507162

Wiesmeier, M., Lungu, M., Hübner, R., Cerbari, V., 2015. Remediation of degraded 694 arable steppe soils in Moldova using vetch as green manure. Solid Earth 6, 609-620.

Wyrwicka, A., Steffani, S., Urbaniak, M., 2014. The effect of PCB-contaminated sewage sludge and sediment on metabolism of cucumber plants (Cucumis sativus L.). Ecohydrology and Hydrobiology 14, 75-82.

Wyrwicka, A., Urbaniak, M. 2018. The biochemical response of willow plants (Salix viminalis L.) to the use of sewage sludge from various sizes of wastewater treatment plant. Science of the Total Environment 615; 882-894 https://doi.org/10.1016/j.scitotenv.2017.10.005 editor. Lipid Peroxides in Biology and Medicine. London, New York: Acad Press Inc; 1982. pp. 223-241. stocks and reduces soil organic matter stability in Mediterranean vegetable gardens. Land Degradation and Development 28, 691-698. antioxidant system responses in tobacco cell suspension cultures. Chemosphere $88 ; 798-805$. 
710 Zhang H, Chen J, Ni Y, Zhang Q, Zhao L. 2009. Uptake by roots and translocation to 711 shoots of polychlorinated dibenzo-p-dioxins and dibenzofurans in typical crop plants. 712 Chemosphere. 76 (6): 740-746. doi: 10.1016/j.chemosphere.2009.05.030 PMID: 19541345

713 Zar J. H. 2010. Biostatistical Analysis, 5th Edition. Upper Saddle River, N.J.: Prentice 714 Hall/Pearson.

715 
Figure 1 (on next page)

The average PCB concentration (average \pm SD) in the soil fertilized with SS from LM WWTP (green bars) and SED from SSBS (blue bars), before and after five weeks of cultivation 
Fig. 1

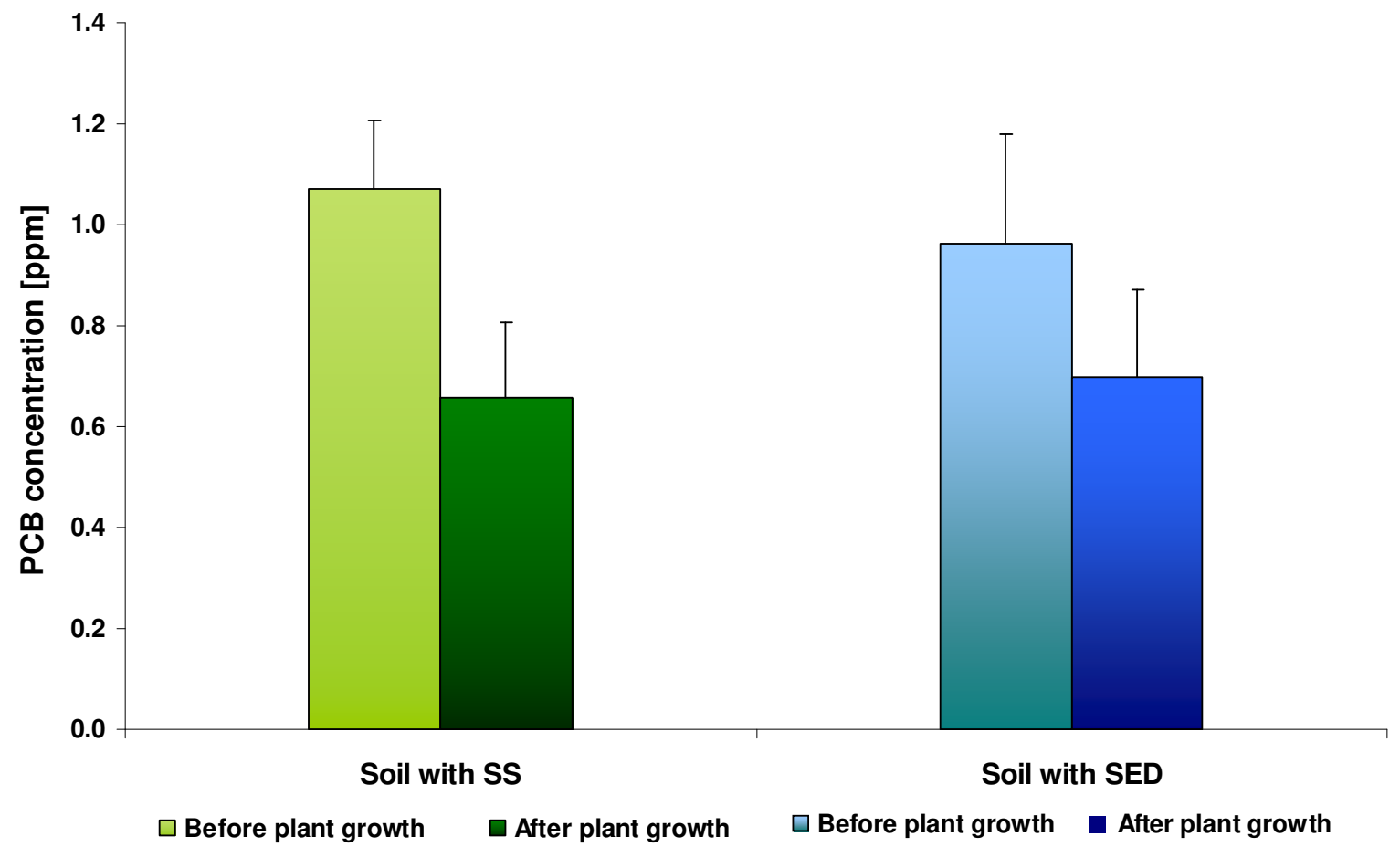

Fig. 1. The average PCB concentration (average \pm SD) in the soil fertilized with SS from LM WWTP (green bars) and SED from SSBS (blue bars), before and after five weeks of cultivation. 


\section{Figure 2 (on next page)}

The PCBs concentration (average $\pm 95 \% \mathrm{CL}$ ) in the soil fertilized with SS from LM WWTP (green bars, Fig. 2a) and SED from SSBS (blue bars, Fig. 2b), before and after five weeks of cultivation.

Asterisks denote a significant difference at the 0.05 (the LSD Fisher post hoc test) 
Fig. 2a

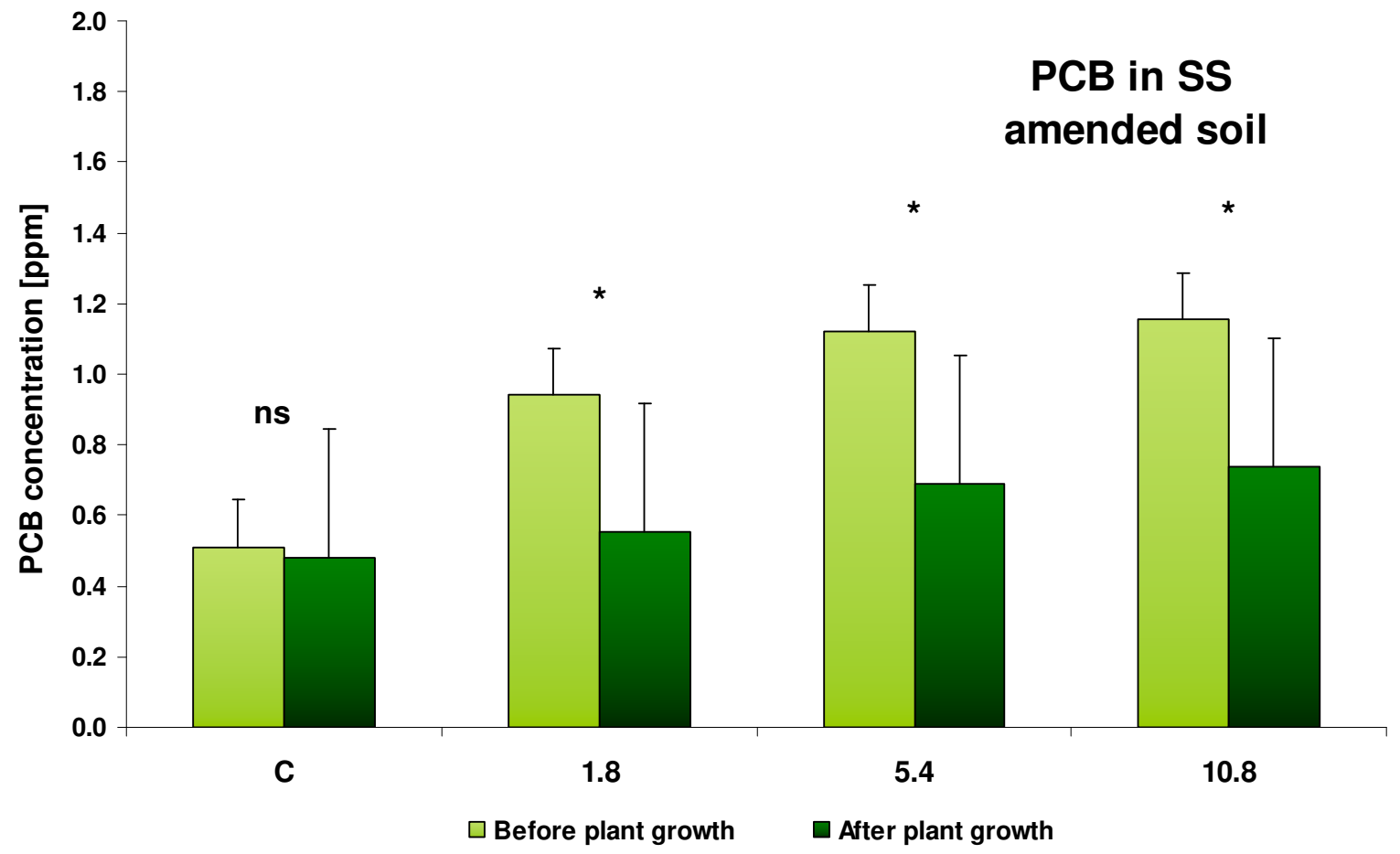

Fig. $2 b$

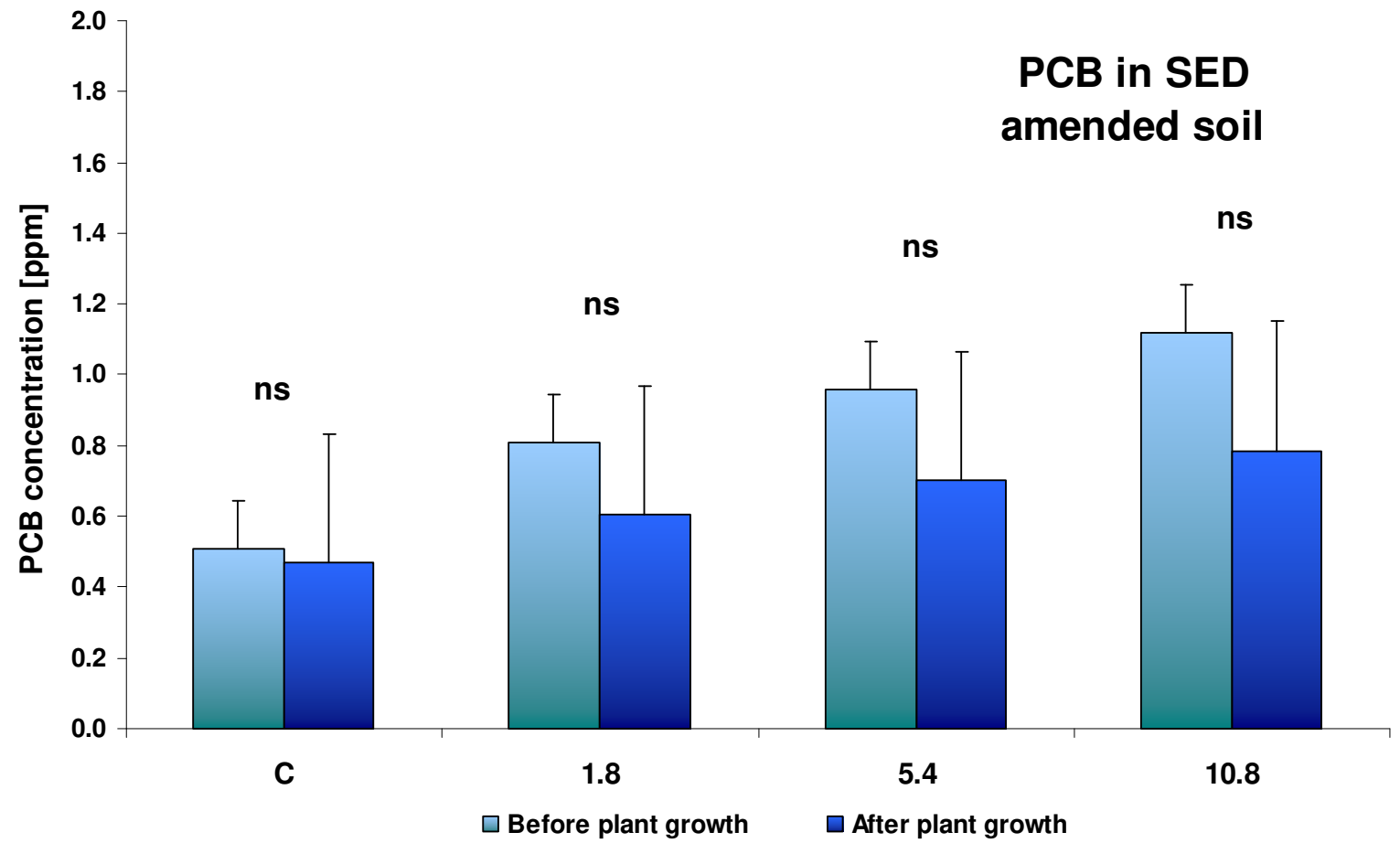

Fig. 2. The PCBs concentration (average $\pm 95 \%$ CL) in the soil fertilized with SS from LM WWTP (green bars, Fig. 2a) and SED from SSBS (blue bars, Fig. 2b), before and after five weeks of cultivation. Asterisks denote a significant difference at the 0.05 level and 'ns' when $\mathrm{p}>0.05$ (the LSD Fisher post hoc test). 
Figure 3 (on next page)

Soluble protein content in control cucumber leaves and in leaves of plants grown on soil amended with SS from LM WWTP (green bars) or SED from SSBS (blue bars) at different doses after five weeks of cultivation

The same letters denote groups that did not statistically differ (the LSD Fisher post hoc test) 
Fig. 3

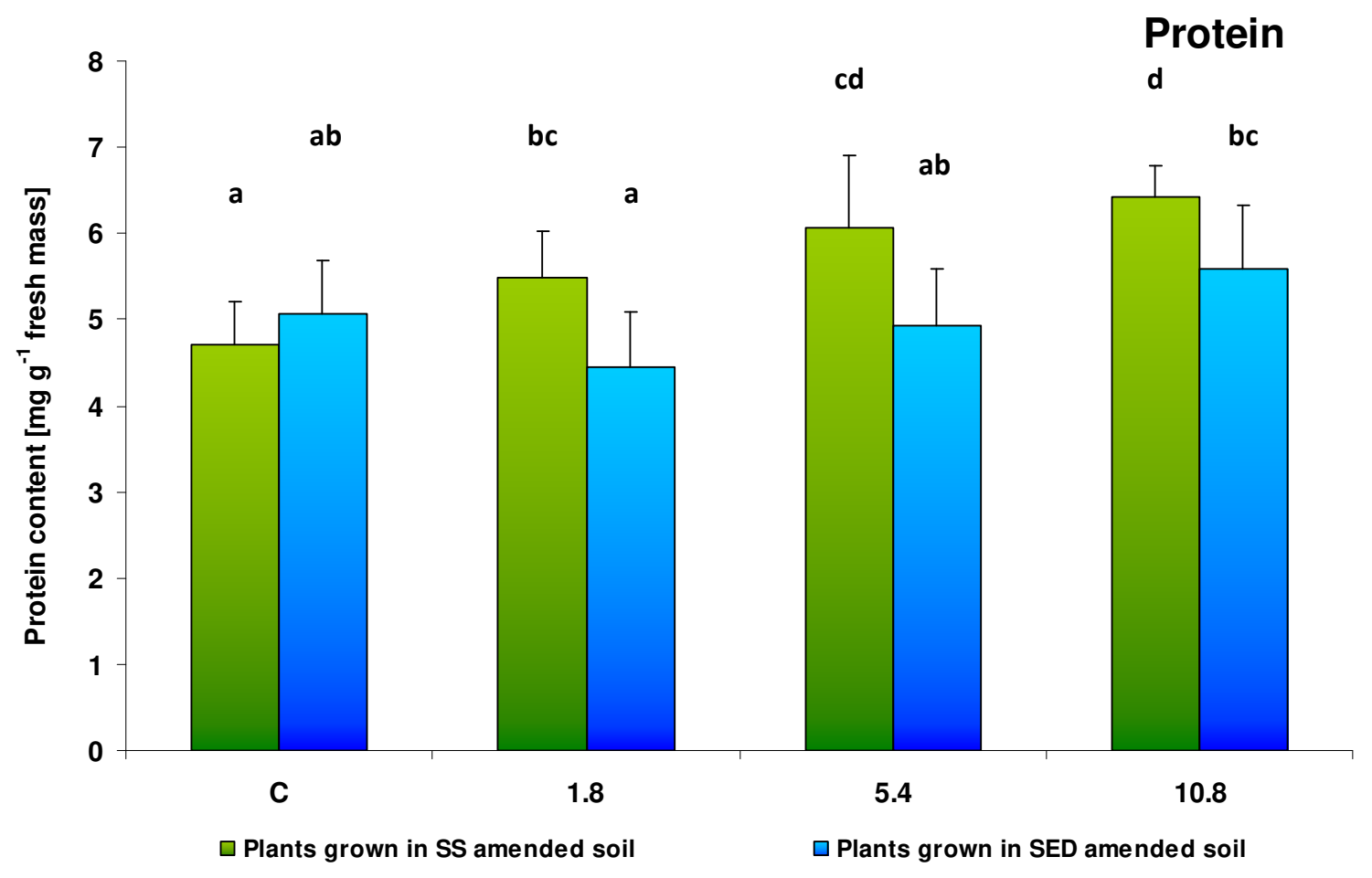

Fig. 3. Soluble protein content in control cucumber leaves and in leaves of plants grown on soil amended with SS from LM WWTP (green bars) or SED from SSBS (blue bars) at different doses after five weeks of cultivation. The same letters denote groups that did not statistically differ (the LSD Fisher post hoc test). 


\section{Figure 4 (on next page)}

TBARS content in control cucumber leaves and in leaves of plants grown on soil amended with SS from LM WWTP (green bars) or SED from SSBS (blue bars) used in different doses after five weeks of cultivation.

The same letters denote groups that did not statistically differ (the LSD Fisher post hoc test. 
Fig. 4

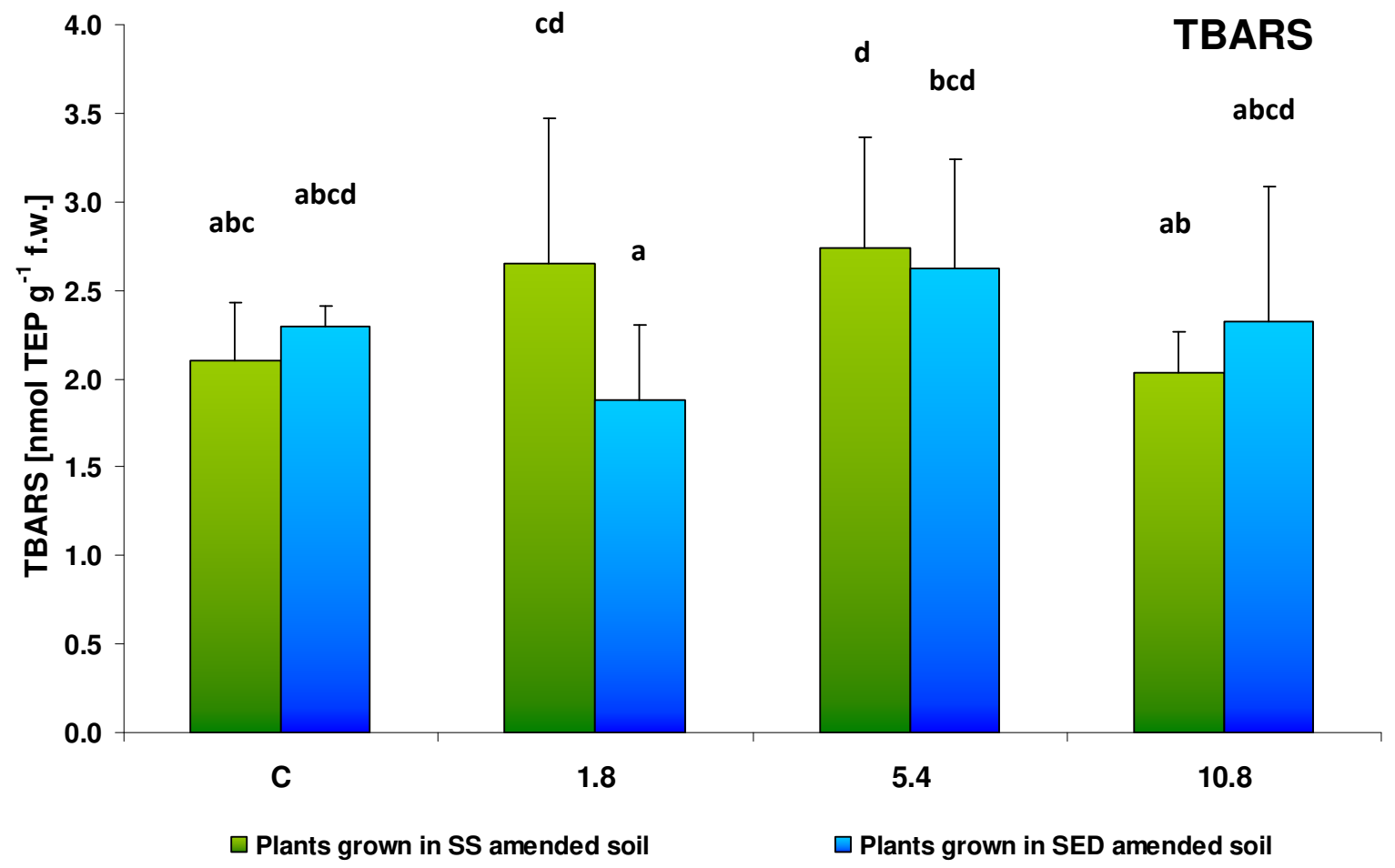

Fig. 4. TBARS content in control cucumber leaves and in leaves of plants grown on soil amended with SS from LM WWTP (green bars) or SED from SSBS (blue bars) used in different doses after five weeks of cultivation. The same letters denote groups that did not statistically differ (the LSD Fisher post hoc test). 
Figure 5 (on next page)

APx activity in control cucumber leaves and in leaves of plants grown on soil amended with SS from LM WWTP (green bars) or SED from SSBS (blue bars) used at various doses after five weeks of cultivation.

The same letters denote groups that did not statistically differ (the LSD Fisher post hoc test. 
Fig. 5

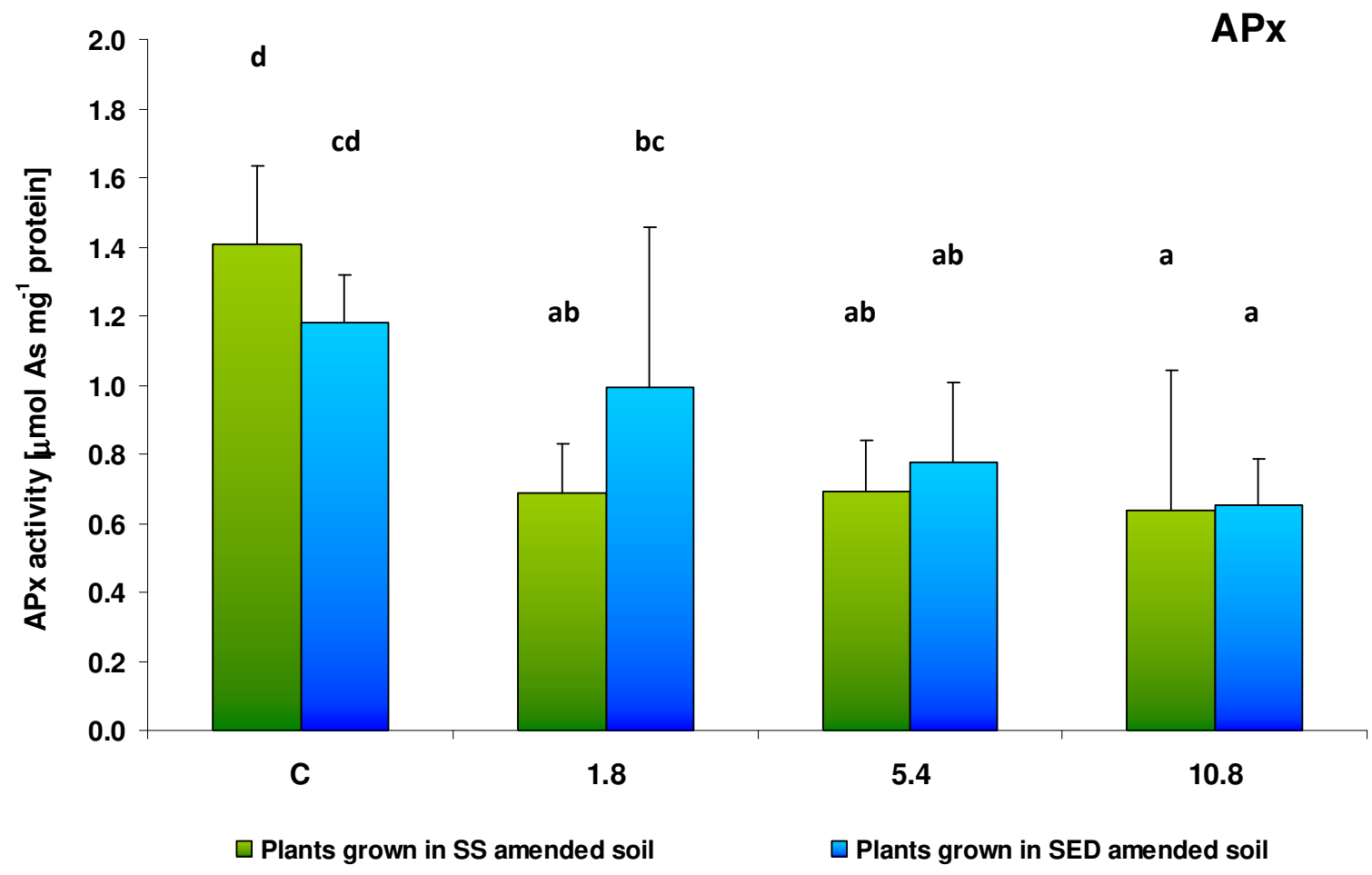

Fig. 5. APx activity in control cucumber leaves and in leaves of plants grown on soil amended with SS from LM WWTP (green bars) or SED from SSBS (blue bars) used at various doses after five weeks of cultivation. The same letters denote groups that did not statistically differ (the LSD Fisher post hoc test). 


\section{Figure 6 (on next page)}

CAT activity in control cucumber leaves and in leaves of plants grown on soil amended with SS from LM WWTP (green bars) or SED from SSBS (blue bars) used in different doses after five weeks of cultivation.

The same letters denote groups that did not statistically differ (the LSD Fisher post hoc test. 
Fig. 6

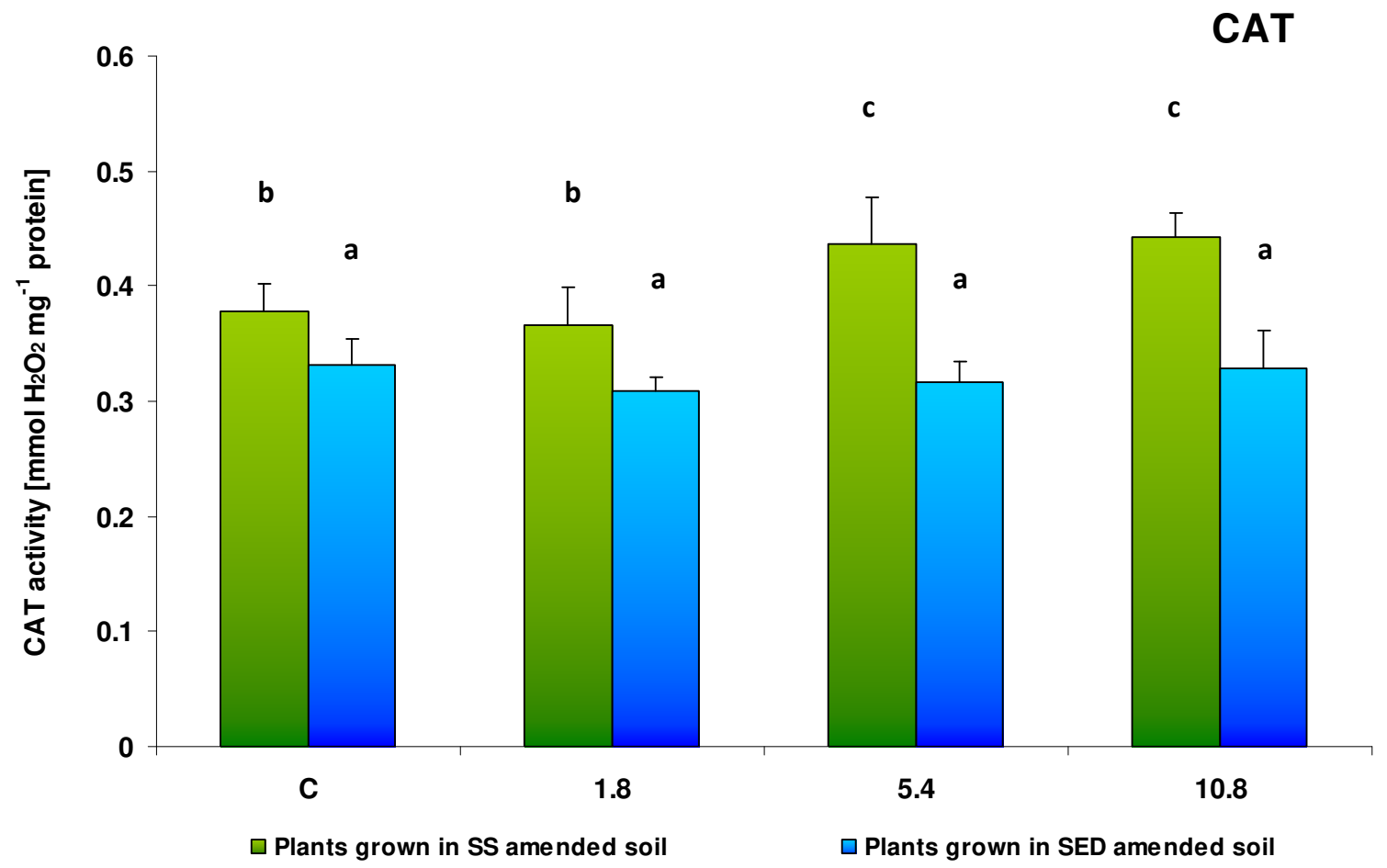

Fig. 6. CAT activity in control cucumber leaves and in leaves of plants grown on soil amended with SS from LM WWTP (green bars) or SED from SSBS (blue bars) used in different doses after five weeks of cultivation. The same letters denote groups that did not statistically differ (the LSD Fisher post hoc test). 


\section{Table $\mathbf{1}$ (on next page)}

Physico-chemical properties of the untreated and soil amended with SS at the dose of 9 $\mathrm{t} \cdot \mathrm{ha}^{-1}$ 
1 Table 1. Physico-chemical properties of the untreated and soil amended with SS at the dose of $9 \mathrm{t} \cdot \mathrm{ha}^{-1}$.

\begin{tabular}{|c|c|c|c|}
\hline Properties & Unit & Control soil & Soil mixed with $\mathbf{9}$ t.ha-1 of SS \\
\hline $\mathbf{p H}$ & - & 6.02 & 6.4 \\
\hline total organic carbon & $\mathrm{g} \cdot \mathrm{kg}^{-1}$ & 15.18 & 22.67 \\
\hline total nitrogen & $\%$ & 0.52 & 0.66 \\
\hline $\mathrm{N}-\mathrm{NO}_{3}$ & $\mathrm{mg} \cdot \mathrm{kg}^{-1} \mathrm{~d} . \mathrm{w}$. & 782 & 859 \\
\hline $\mathbf{P}$ & $\mathrm{mg} \cdot \mathrm{kg}^{-1} \mathrm{~d} . \mathrm{w}$. & 437 & 728 \\
\hline $\mathbf{K}$ & $\mathrm{mg} \cdot \mathrm{kg}^{-1} \mathrm{~d} . \mathrm{w}$. & 2341 & 2809 \\
\hline
\end{tabular}


Table 2 (on next page)

Two-way analysis of variance (repeated measures ANOVA II) results to test the effects of the dose of applied amendments (0, 1.8, 5.4 and 10.8), the type of soil amendments (SS and SED) on decreases in soil PCB content after five weeks of cultivation. 
1 Table 2. Two-way analysis of variance (repeated measures ANOVA II) results to test 2 the effects of the dose of applied amendments (0,1.8, 5.4 and 10.8), the type of soil 3 amendments (SS and SED) on decreases in soil PCB content after five weeks of 4 cultivation.

5

\begin{tabular}{rcccc}
\hline Effect & df & MS & F & $p$ \\
\hline Dose of applied amendments (A) & 3 & 0.3203 & 10.1294 & 0.0042 \\
Soil amendment type (B) & 1 & 0.0066 & 0.2091 & 0.6596 \\
A×B & 3 & 0.0027 & 0.0862 & 0.9656 \\
Error & 8 & 0.0316 & & \\
PCB decrease (C) & 1 & 0.5544 & 22.1443 & 0.0015 \\
C $\times$ A & 3 & 0.0481 & 1.9198 & 0.2049 \\
C $\times$ B & 1 & 0.0231 & 0.9232 & 0.3648 \\
C $\times$ B $\times$ A & 3 & 0.0040 & 0.1580 & 0.9216 \\
Error & 8 & 0.0250 & & \\
& & & &
\end{tabular}

6 


\section{Table 3(on next page)}

The effect of the application of SS from LM WWTP and SED from SSBS on total chlorophyll content, as well as chlorophyll a/b ratio (both average \pm SD) of cucumber leaf tissues after five weeks of cultivation.

The same letters denote groups that did not statistically differ (the LSD Fisher post hoc test). 
1 Table 3. The effect of the application of SS from LM WWTP and SED from SSBS on 2 total chlorophyll content, as well as chlorophyll a/b ratio (both average $\pm S D$ ) of 3 cucumber leaf tissues after five weeks of cultivation. The same letters denote groups 4 that did not statistically differ (the LSD Fisher post hoc test). 5

\section{Soil with}

\begin{tabular}{cccc}
\hline & $\begin{array}{c}\text { Soil with } \\
\text { Dose of } \\
\text { applied } \\
\text { amendments }\end{array}$ & SS & SED \\
\hline Total chlorophyll & $\mathbf{C}$ & $2.380^{\mathrm{ab}} \pm 0.233$ & $2.467^{\mathrm{ab}} \pm 0.481$ \\
[mg g $^{-1}$ f.m.] & $\mathbf{1 . 8}$ & $2.495^{\mathrm{ab}} \pm 0.240$ & $2.485^{\mathrm{ab}} \pm 0.096$ \\
& $\mathbf{5 . 4}$ & $2.624^{\mathrm{ab}} \pm 0.447$ & $2.315^{\mathrm{a}} \pm 0.123$ \\
& $\mathbf{1 0 . 8}$ & $2.656^{\mathrm{b}} \pm 0.242$ & $2.491^{\mathrm{ab}} \pm 0.397$ \\
\hline $\begin{array}{c}\text { Chlorophyll a/b } \\
\text { ratio }\end{array}$ & $\mathbf{C}$ & $2.083^{\mathrm{a}} \pm 0.065$ & $2.023^{\mathrm{b}} \pm 0.019$ \\
& $\mathbf{1 . 8}$ & $2.082^{\mathrm{a}} \pm 0.024$ & $2.067^{\mathrm{ab}} \pm 0.020$ \\
& $\mathbf{5 . 4}$ & $2.075^{\mathrm{ab}} \pm 0.036$ & $2.062^{\mathrm{ab}} \pm 0.036$ \\
\hline
\end{tabular}

